\title{
The influence of sample distribution on growth model output for a highly-exploited marine fish, the Gulf Corvina (Cynoscion othonopterus)
}

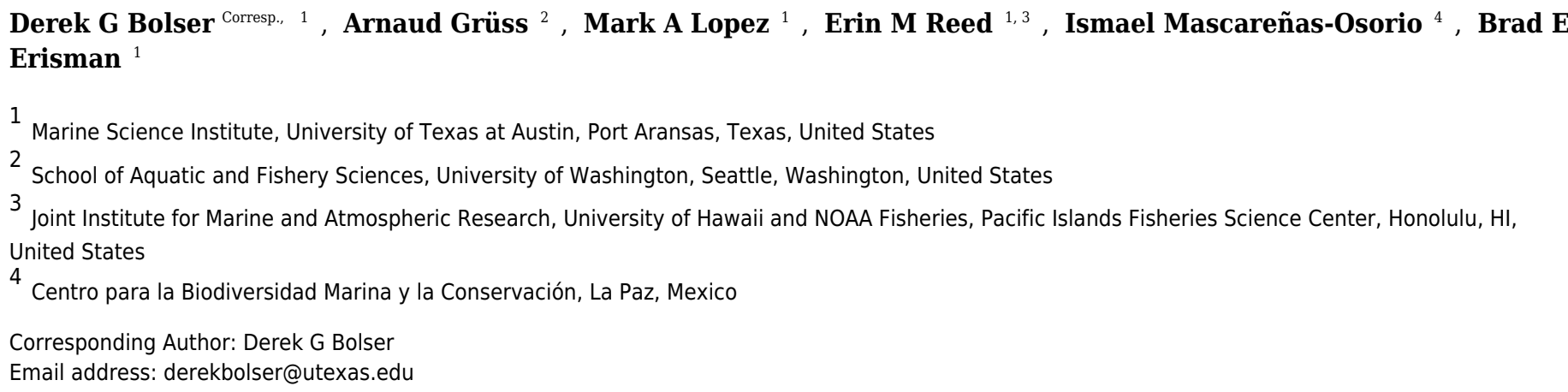

Estimating the growth of fishes is critical to understanding their life history and conducting fisheries assessments. It is imperative to sufficiently sample each size and age class of fishes to construct models that accurately reflect biological growth patterns, but this may be a challenging endeavor for highly-exploited species in which older fish are rare. Here, we use the Gulf Corvina (Cynoscion othonopterus), a vulnerable marine fish that has been persistently overfished for two decades, as a model species to compare the performance of several growth models. We fit the von Bertalanffy, Gompertz, logistic, Schnute, and Schnute-Richards growth models to length-at-age data by nonlinear least squares regression and used simple indicators to reveal biased data and ensure our results were biologically feasible. We then explored the consequences of selecting a biased growth model with a per-recruit model that estimated female spawning-stock-biomass-per-recruit and yield-per-recruit. Based on statistics alone, we found that the Schnute-Richards model described our data best. However, it was evident that our data were biased by a bimodal distribution of samples and underrepresentation of large, old individuals, so we found the Schnute-Richards model output to be biologically implausible. By simulating an equal distribution of samples across all age classes, we found that sample distribution distinctly influenced model output for all growth models tested. Consequently, we determined that the growth pattern of the Gulf Corvina was best described by the von Bertalanffy growth model, which was the most robust to biased data, comparable across studies, and statistically comparable to the Schnute-Richards model. Growth model selection had important consequences for assessment, as the per-recruit model employing the SchnuteRichards model fit to raw data predicted the stock to be in a much healthier state than 
per-recruit models employing other growth models. Our results serve as a reminder of the importance of complete sampling of all size and age classes when possible, and transparent identification of biased data when complete sampling is not possible. 
1 The influence of sample distribution on growth model output for a highly-exploited marine

2 fish, the Gulf Corvina (Cynoscion othonopterus)

3 Derek G. Bolser ${ }^{1}$, Arnaud Grüss ${ }^{2}$, Mark A. Lopez ${ }^{1}$, Erin M. Reed ${ }^{1,3}$, Ismael Mascareñas-Osorio ${ }^{4}$, 4 and Brad E. Erisman ${ }^{1}$

5 'Marine Science Institute, The University of Texas at Austin, 750 Channel View Drive, Port

6 Aransas, TX 78373, USA

$7{ }^{2}$ School of Aquatic and Fishery Sciences, University of Washington, Box 355020, Seattle, WA, 8 98105-5020, USA

9 3Present address: Joint Institute for Marine and Atmospheric Research, University of Hawaii and 10 NOAA Fisheries, Pacific Islands Fisheries Science Center, 1000 Pope Road, Marine Sciences

11 Building 312, Honolulu, HI 96822, USA

$12{ }^{4}$ Centro para la Biodiversidad Marina y la Conservación, Calle del Pirata 420, Col. Benito

13 Juarez, La Paz, BCS, 23090, Mexico

14 Corresponding Author:

Derek Bolser ${ }^{1}$

16 Author email address: derekbolser@utexas.edu 


\section{Abstract}

18 Estimating the growth of fishes is critical to understanding their life history and conducting

19 fisheries assessments. It is imperative to sufficiently sample each size and age class of fishes to construct models that accurately reflect biological growth patterns, but this may be a challenging endeavor for highly-exploited species in which older fish are rare. Here, we use the Gulf Corvina (Cynoscion othonopterus), a vulnerable marine fish that has been persistently overfished for two decades, as a model species to compare the performance of several growth models. We fit the von Bertalanffy, Gompertz, logistic, Schnute, and Schnute-Richards growth models to length-atage data by nonlinear least squares regression and used simple indicators to reveal biased data and ensure our results were biologically feasible. We then explored the consequences of selecting a biased growth model with a per-recruit model that estimated female spawning-stockbiomass-per-recruit and yield-per-recruit. Based on statistics alone, we found that the SchnuteRichards model described our data best. However, it was evident that our data were biased by a bimodal distribution of samples and underrepresentation of large, old individuals, so we found the Schnute-Richards model output to be biologically implausible. By simulating an equal distribution of samples across all age classes, we found that sample distribution distinctly influenced model output for all growth models tested. Consequently, we determined that the growth pattern of the Gulf Corvina was best described by the von Bertalanffy growth model, which was the most robust to biased data, comparable across studies, and statistically comparable to the Schnute-Richards model. Growth model selection had important consequences for assessment, as the per-recruit model employing the Schnute-Richards model fit to raw data predicted the stock to be in a much healthier state than per-recruit models employing other growth models. Our results serve as a reminder of the importance of complete sampling of all 
40 size and age classes when possible, and transparent identification of biased data when complete

41 sampling is not possible.

\section{Introduction}

Age and size data inform estimates of life history parameters that are crucial to fisheries

44 stock assessments. In early assessments such as Beverton and Holt's yield-per-recruit model (1957), size at age was critical for estimating reproductive output and thus the sustainability of

fisheries. In today's age-structured stock assessments, size at age is used to convert from biomass to number of fish, determine selectivity, and calculate expected length compositions (Francis, 2016). Similarly, size (i.e., length or weight) at age is used in size-structured stock assessment models to inform transitions between size bins and determine length composition (Punt et al., 2016). Accurately representing the relationship between size and age is particularly important for

51 vulnerable fish and in data-poor fisheries, in which life-history parameters and population structure often drive stock assessments and management decisions (Dulvy et al., 2004; Froese,

53 2004; Honey et al., 2010; Hordyk et al., 2016). Specifically, these types of assessments rely

54 heavily on age-length data to confer insights on vulnerability and overfishing (Erisman et al., 55 2014).

When modelling the relationship between age and size for the purposes of assessment, and

57 for any purpose, each age and size class must be sufficiently represented to generate growth parameters that reflect biological growth (Cailliet et al., 1986; Cailliet and Tanaka, 1990; Francis

59 and Francis, 1992; Cailliet and Goldman, 2004). It is important to make the distinction between

60 this type of sampling and sampling to reflect population structure, which should not be the goal

61 of age and growth studies as this reflects bias due to the relative scarcity of large and old 
62 individuals. Sufficiently representing each size and age class may be especially difficult in

63 highly-exploited species, as exploitation alters the population structure of fishes by preferentially

64 selecting for large and old fish individuals (Mason, 1998; Berkeley et al., 2004). The

65 ramifications for failing to acknowledge selection are clear, as length-selective fishing mortality

66 distorts growth curves (Walker et al., 1998). Further, the lack of representation of large and old

67 individuals could result in underestimation of lifespan and longevity, which makes fishery

68 management measures less effective (Campana, 2001; Cailliet and Andrews, 2008; Goldman et

69 al., 2012). Large and old fish drive estimates of the maximum average length parameter $L_{\infty}$, and

70 without them, $L_{\infty}$ is underestimated and the growth rate (typically denoted by $K$ ) is

overestimated. The underestimation of $L_{\infty}$ and the overestimation of $K$ lead to the assumptions of

72 a shorter generation time and less mortality, and thus more resiliency to high levels of fishing

73

74

75 pressure (Campana, 2001; Goldman et al., 2012; Harry, 2017). The $L_{\infty}$ term is particularly important when growth models are incorporated into stock assessment (Wells et al., 2013). This problem may also occur in growth modelling for vulnerable fish or in data-poor fisheries, where lack of representation of each age and size class due to sampling constraints or the scarcity of individuals may similarly affect parameter estimates. Fishery dependent data are often the only data available for growth modelling, which may be acceptable only as long as the inherent biases and limitations are acknowledged.

Several models have been developed to quantify the relationship between age and size, with body length being the most common metric of size. Typically, asymptotic growth models are used to quantify this relationship. These models describe fast growth rate in the earliest years of life and slower growth in later years. Despite some criticism (Roff, 1980; Czarnołe'ski and Kozlowski, 1998), the most widely used is the von Bertalanffy growth model (Chen et al., 1992; 
85 Kimura, 2008). Rooted in bioenergetics, this model is intended to give a biologically relevant

86

87

88

89

90

91

92

93

94

95

96

97

98

representation of how catabolic and anabolic processes work within a fish to change growth over the lifespan of fishes (von Bertalanffy, 1938; Pauly, 2010). Over the years, there have been many re-parameterizations of von Bertalanffy with incorporation of growth-influencing factors and applications to a variety of situations (Gallucci II and Quinn, 1979; Ratkowsky, 1986; Helser and Lai, 2004; Kimura, 2008; Brunel and Dickey-Collas, 2010; van Poorten and Walters, 2016), but the original parametrization is still the most commonly used (Lorenzen, 2016). Other asymptotic growth models are commonly used in fisheries, such as the Gompertz growth model (Gompertz, 1825) and the logistic growth model (Ricker, 1975).

In recent years, fish growth models have moved from a foundation in bioenergetics to being more statistically driven (van Poorten and Walters, 2016). These models are inherently more flexible, allowing them to capture subtleties in growth patterns that may not be captured by the more inflexible growth models. The Schnute model (Schnute, 1981), for example, has four curve families that the model may assume based on which types of data the model is fit to and what other functions are incorporated into the framework. Another flexible growth model, the Schnute-Richards model (Schnute and Richards, 1990), can describe biphasic growth among several other forms. By design, the Schnute-Richards model may be equivalent to the other growth models discussed above when the proper values are specified for its dimensionless parameters. Fish growth is inherently plastic and fish do not all grow the same way (Weatherley, 1990; Lorenzen, 2016), so a flexible growth model may be advantageous in certain situations. However, these flexible models may also be more sensitive to sampling biases in data, potentially producing growth patterns that reflect the size-frequency distribution of fish collected rather than the biological growth pattern of the species. 
performance of multiple growth models in a vulnerable marine fish. Endemic to the northern the International Union for the Conservation of Nature (IUCN) Redlist (Chao et al., 2016). Gulf decades, which have resulted in growing concern for the fishery's stability and longevity

114 (Erisman et al., 2012; Ruelas-Peña et al., 2013; Erisman et al., 2014; Ortiz et al., 2016). The life history of this species has been well documented and provides an ideal foundation for future analysis of individual and population growth (Román-Rodriguez, 2000; Gherard et al., 2013. With a documented maximum size of $1013 \mathrm{~mm}$ total length (TL) and a documented maximum age of 9 years, Gulf Corvina is a fast growing, short lived species which reaches sexual maturity at 2 years of age (Gherard et al., 2013). However, the combination of highly efficient, sizeselective gear and persistent overfishing have severely truncated the age structure of the population (Erisman et al., 2014; Ortiz et al., 2016). The mean age of capture of Gulf Corvina is 5 years ( $c a .700 \mathrm{~mm} \mathrm{TL}$ ), and few individuals older than age 7 or younger than age 4 have been observed in the fishery (Gherard et al., 2013; Erisman et al., 2014; Ortiz et al., 2016).

Past studies of Gulf Corvina growth, which have relied solely on fishery-dependent data with incomplete sampling of all size and age classes, have produced different results due to differences in model selection approach. Based on the congruence of the model with the growth pattern of many species of the genus Cynoscion and other sciaenid fishes (Rutherford et al., 1982; Lowerre-Barbieri et al., 1995; Rodriguez and Hammann, 1997), Gherard et al. (2013) took

129 a conservative, single model approach and fit the von Bertalanffy growth model to Gulf Corvina age-length data. Conversely, Aragón-Noriega (2014) chose a statistically-driven approach and fit 
131 several models to multiple datasets, concluding that Gulf Corvina grew in a biphasic pattern with

132 slow growth in the beginning of life, rapid growth after age two, and slow growth after age four.

133 Notably, Aragón-Noriega's (2014) estimates for the $L_{\infty}$ parameter varied greatly, from 735.0 to

$1341126.6 \mathrm{~mm}$, depending on which dataset was used. Given this variability, absence of biphasic

135 growth patterns in similar sciaenids, and the distance from the maximum observed length of Gulf

136 Corvina (1013 mm; Gherard et al., 2013), Aragón-Noriega’s (2014) estimates may be

137 biologically unrealistic. Mendivil-Mendoza et al. (2017) took a similar approach and found a

138 similarly wide range of $L_{\infty}$ values $(666.7-1306.0 \mathrm{~mm})$. However, despite fitting models to

139 similar data and selecting the same model as Aragón-Noriega (2014), Mendivil-Mendoza et al.

140 (2017) did not describe the biphasic growth pattern recorded by Aragón-Noriega (2014). The

141 existence of discrepancies between the previous Gulf Corvina growth studies and the importance

142 of the age-length relationship to the stock assessment of the fishery merit further investigation on

143 the growth pattern of the species.

Here, we model the growth of Gulf Corvina and draw conclusions about data needs and

fisheries assessments. Our specific objectives were to: (1) assess how representation of size and age classes affected growth parameter estimates and (2) compare the performance of multiple growth models for describing age-at-length data for Gulf Corvina. Through generating a more complete dataset than previous studies and testing for biases in our data with simple indicators, we addressed these objectives. Moreover, using the results of simulations with a per-recruit model, we discussed the implications of misrepresenting growth in highly-exploited, vulnerable marine fishes. 

three locations in the upper Gulf of California: El Golfo de Santa Clara (Sonora), San Felipe (Baja California), and El Zanjón (Baja California). Information on total length (TL) was

157

recorded to the nearest $\mathrm{mm}$ for each fish collected, and the sagittal otoliths were removed, dried whole and stored until further use. Five hundred and thirty of these samples were collected from the commercial Gulf Corvina fishery and from bycatch from the shrimp fishery. These data were used by Gherard et al. (2013). In order to increase representation of size and age classes that were scarce in the dataset used by Gherard (2013), we collected 219 additional samples in 20122013 from the bycatch of other fisheries (e.g., shrimp), fishery-independent sampling of small individuals ( $<30 \mathrm{~cm}$ TL), and the commercial Gulf Corvina fishery. All fish were deceased at the time of collection from fishers. The research protocol was approved under UCSD IACUC ID no. S13240 and data were collected under CONANP permit no. CNANP-00-007.

Otolith preparation and ageing protocols were followed according to the methods developed by Gherard et al. (2013) for Gulf Corvina. Whole sagittal otoliths were first mounted on wood blocks with a cyanoacrylate adhesive and a $0.5 \mathrm{~mm}$ dorsal-ventral cross-section was cut through the otolith focus using a double-bladed Buehler Isomet 1000 precision saw (Allen et al., 1995). Sub-sections were then mounted on a glass slide using thermoplastic glue and submerged in a glass petri dish with water and a black background. Transmitted light under a Zeiss Stemi 2000-C microscope with a Zeiss Axiocam 105 color camera at $6.25 x$ total magnification was used to count the alternating opaque and translucent growth zones that define an annulus (Figure 1). For the purposes of this study, an annulus was defined as one full opaque and translucent zone of growth (Cailliet et al., 1996), which was validated for Gulf Corvina by previous studies (Rowell et al., 2005; Román-Rodriguez, 2000; Gherard et al., 2013) Each otolith was aged by 
177 two independent readers from digital images of cross-sections, as direct observation through the

178 scope did not distort band pattern and did not affect age estimates. Samples were excluded from

179 analysis when discrepancies between readers occurred.

180

181

182

183

184

185

186

187

191

192

193

194

\section{Model fitting and assessment of fit}

\section{Growth modelling}

A suite of growth models was fit to age data determined from otoliths as described, and length data obtained in the field. Model parameters were estimated using non-linear least squares regression with the Levenberg-Marquardt algorithm, and confidence limits were placed around parameter estimates in R studio (using the R packages FSA, minpack.lm, and nlstools).

The specialized von Bertalanffy growth model (von Bertalanffy, 1938) is given by:

Eq. 1:

$$
L(t)=L_{\infty}\left[1-e^{-K\left(t-t_{0}\right)}\right]
$$

where $L(t)$ is size (in mm TL) at age $t, L_{\infty}$ is the maximum average length (in mm TL), $K$ is the growth rate coefficient (in year ${ }^{-1}$ ), and $t_{0}$ is the theoretical age at which length is zero (in years).

The Gompertz growth model (Gompertz, 1825) is given by:

Eq. 2: $\quad L(t)=L_{\infty} e^{\left(-\left(\frac{1}{K}\right) e^{-K\left(t-t_{0}\right)}\right)}$

where the parameters are the same as described for Eq. 1.

The logistic model (Ricker, 1975) is given by:
Eq. 3:
$L(t)=L_{\infty}\left[1+e^{-K\left(t-t_{0}\right)}\right]^{-1}$ 
195 where the parameters are the same as described for Eqs. 1 and 2.

196

197

Eq. 4:

$$
L(t)=\left[L_{1}{ }^{b}+\left(L_{2}{ }^{b}-L_{1}{ }^{b}\right) \frac{1-e^{-a\left(t-\mathrm{T}_{1}\right)}}{1-e^{-a\left(\mathrm{~T}_{2}-\mathrm{T}_{1}\right)}}\right] 1 / b
$$

198

202 relative rate of relative growth (dimensionless),

Eq. 5:

$$
L(t)=L_{\infty}\left(1+\alpha e^{-a t^{c}}\right)^{1 / b}
$$

where $\alpha, b$, and $c$ are dimensionless parameters, and $a$ has the unit of year ${ }^{-b}$.

\section{Statistical measures of fit} 1978) in R Studio (using the R package AICcmodavg).

The formula for AICc is given by:

Eq. 6:

$$
A I C_{c}=A I C+\frac{2 k(k+1)}{n-k-1}
$$

where:

Eq. 7:

$$
A I C=-2 \log (L)+2 k
$$
The formula for BIC is given by:

where $T_{1}$ is the first specified age, $T_{2}$ is the second specified age, $L_{l}$ is size at age $T_{1}, L_{2}$ is size at age $T_{2}, a$ is the constant relative rate of relative growth (in year-1), and $b$ is the incremental

Finally, the Schnute-Richards model (Schnute and Richards, 1990) is given by:

Model fit was assessed with the bias-corrected Akaike Information Criterion (AICc)

(Shono, 2000; Burnham and Anderson, 2004), and Bayesian Information Criterion (Schwarz,

and $n$ is the number of observations, $k$ is the number of model parameters, and $L$ is the likelihood. 
214 Eq. 8:

$$
B I C=2 \ln (L)+k \log (n)
$$

215 where parameter definitions are the same as described for Eq. 7.

217 two criteria is that AICc is designed to select the model that describes reality the best while

218 treating no models as true, which is consistent with an information theory approach, whereas

219 BIC is designed to select the true model. Practically, BIC penalizes for the number of parameters 220 more heavily than AICc. AICc was used instead of AIC as it is bias-corrected at small $n$ values

221 or high k:n ratios; AICc converges to AIC at large $n$ values (Burnham and Anderson, 2004).

222 AICc and BIC values were calculated to show the absolute difference between model fits. Next, 223 AICc weights were calculated for model averaging of parameter estimates; the AIC weighting 224 formula is given by:

225 Eq. 9:

$$
w_{i}=\frac{e\left(-0.5 \Delta_{i}\right)}{\sum_{k=1}^{5} e\left(-0.5 \Delta_{k}\right)}
$$

where parameter definitions are the same as described for Eqs. 7 and 8.

Simple indicators of biased data

To test for the influence of sampled population structure on growth model output, different amounts of simulated data were added to raw data so that each age observed (1-8) had 200 total observations. Data were simulated from a normal distribution with the same mean and standard deviation as the raw data at each age class. This simulation was not intended to generate the true population structure of Gulf Corvina in the Gulf of California, but rather to generate an equal number of samples in each age and size class. This simulation did not explicitly account for 
235 selectivity or limits in sampling effort, but filled in gaps left by these factors and others that

236 prevented more equal representation of each size and age class in the raw data. Models were fit

237 to the new dataset and goodness of fit was assessed in the same manner as was described above.

Froese and Binohlan's (2000) empirical relationship between the longest fish in the data set $\left(L_{\text {max }}\right)$ and $L_{\infty}$ was used to specifically test for the influence of the lack of large and old fish in the raw dataset, which is likely due to heavy exploitation. If large and old fish are insufficiently represented in the dataset, it stands to reason that the $L_{\infty}$ predicted by this relationship will be greater than the modelled $L_{\infty}$. This relationship is given by:

Eq. 10:

$$
\log L_{\infty}=0.044+0.9841 * \log \left(L_{\text {max }}\right)
$$

\section{Literature review}

A brief literature review of sciaenid growth modelling was conducted to assess how the results of this study compared with other studies on fishes closely related to the Gulf Corvina relationship and the simple simulation of an ideal sampling scenario, this brief literature review was intended to check if the samples used in this study produced a biologically plausible growth pattern when growth was modelled. simulations with a per-recruit model detailed in Appendix S1. In brief, this per-recruit model 
256 estimates the female spawning-stock-biomass-per-recruit (SSBR; a proxy of reproductive

257 capacity) and yield-per-recruit (YPR; exploitable biomass) of Gulf Corvina in relation to the

258 annual exploitation rates of the old adults ( $\geq 5$ year-old individuals) of the species $\left(E_{O A}\right)$. In this

259 per-recruit model, Gulf Corvina is assumed to grow according to one of five alternative growth

260 models: (1) the von Bertalanffy model developed in Gherard et al. (2013), referred to as the

261 "Gherard model"; (2) the von Bertalanffy model fit to raw data in the present study; (3) the von

262 Bertalanffy model fit to raw data bolstered by simulation values in this study; (4) the Schnute-

263 Richards model fit to raw data in the present study; and (5) the Schnute-Richards model fit to

264 raw data bolstered by simulation values in this study. The current $E_{O A}$ was estimated to be 0.825

265 year $^{-1}$ (Appendix S1). We first ran simulations with the per-recruit model to determine the

266 maximum value of the YPR of Gulf Corvina $\left(\mathrm{YPR}_{\max }\right)$ and the natural SSBR of Gulf Corvina

267 (NSSBR), i.e., its SSBR in the absence of fishing (Appendix S1). Then, we estimated the current

268 fraction of NSSBR (current FNSSBR, i.e., the ratio of current SSBR to NSSBR) and the current

269 YPR over YPR $_{\max }$ of Gulf Corvina, when each of the five abovementioned growth models is

270 used to represent the growth in length of Gulf Corvina.

\section{Results}

272 Length and age structure

273 A bimodal distribution was observed in the length and age structure of the fish used in

274 this study (Figures 2 and 3). The first mode of the distribution represents Gulf Corvina caught as

275 bycatch, whereas the second represents Gulf Corvina caught in the targeted fishery. Lengths

276 ranged from 141-1013 $\mathrm{mm} \mathrm{TL}$, and ages ranged from 1-8 years.

277 Model fitting and assessment of fit for models fit to raw data 
The Gompertz, logistic, and von Bertalanffy models yielded asymptotic growth patterns,

280

281

282

284

285

286

287

288

290

291

292

293

294

295

296

297

298

while the Schnute-Richards model described biphasic growth and the Schnute model described near-linear growth after 1.5 years of life (Figure 4). Modelled length at age was most similar among models at intermediate ages, where samples were most abundant (Figure 4). Conversely, modelled length at age was most variable at young and old ages, where samples were most scarce (Figure 4). Estimates of $L_{\infty}$ ranged from $730.91 \mathrm{~mm}$ (Schnute-Richards model) to 916.05 mm (von Bertalanffy model). All parameter estimates are summarized in Table 1, while confidence intervals around parameter estimates are reported in Appendix S2.

\section{Measures of statistical fit for models fit to raw data}

AICc and BIC values indicated that the Schnute-Richards model described the raw data best, followed by the logistic, Gompertz, von Bertalanffy, and Schnute models (Table 2). The AIC weighting formula gave full support to the Schnute-Richards model, so no model averaging of parameters was necessary.

\section{Simple indicators of biased data}

Growth patterns and parameter estimates for models fit to raw data bolstered by simulated values

The Schnute-Richards, Gompertz, logistic and von Bertalanffy growth models yielded asymptotic growth patterns, while the Schnute model described near-linear growth after 1.5 years of age (Figure 5). Modelled length at age was similar at intermediate ages among all growth models except for the Schnute one, but differed slightly at young and old ages (Figure 5). 
299 Estimates of $L_{\infty}$ ranged from $834.34 \mathrm{~mm}$ (logistic model) to $951.30 \mathrm{~mm}$ (von Bertalanffy model)

300 (Table 3). All parameter estimates for each growth model are summarized in Table 3.

301

302

303

304

305

306

307

308

309

310

311

312

313

314

315

316

317

318

319

320

Measures of statistical fit for models fit to raw data bolstered by simulated values

The von Bertalanffy growth model described the raw data bolstered by simulated values best according to AICc and BIC values (Table 4). However, it was only marginally better than the Schnute-Richards and Gompertz models based on AICc. Thus, the von Bertalanffy growth model received 53\% of AICc weighting to the Schnute-Richards' $33 \%$, and Gompertz' $15 \%$. The logistic model fit the data better than the Schnute model, but neither models received any support from AICc weighting. Model averaging $L_{\infty}$ based on AICc weights resulted in an estimated $L_{\infty}$ of $945 \mathrm{~mm}$, an estimate $6 \mathrm{~mm}$ shorter than the that predicted by the von Bertalanffy model. In contrast to AICc values, BIC values indicated that the Gompertz model fit the data better than the Schnute-Richards model. Both Gompertz and Schnute-Richards models fit the data better than the logistic and Schnute models according to BIC values, as was indicated by AICc values.

\section{Froese and Binohlan's empirical relationship}

Froese and Binohlan's empirical relationship between $L_{\max }$ and $L_{\infty}$ predicted a $L_{\infty}$ of 1006 $\mathrm{mm}$ from a maximum observed length of $1013 \mathrm{~mm}$. This estimate is larger than all estimates of $L_{\infty}$ derived from growth models fit to raw data (Table 1) and raw data bolstered by simulated values (Table 3).

\section{Literature review}

Results from our review of 24 sciaenid growth studies and citations are summarized in Table 5. Age and body length relationships in sciaenids were represented by the von Bertalanffy growth model in 20 of 24 (83\%) of the studies we reviewed, as reported in Atlantic Croaker 
321 (Micropogonias undulatus), Black Drum (Pogonias chromis), Red Drum (Scianops ocellatus),

322 Southern Kingfish (Menticirrhus americanus), Spotted Seatrout (Cynoscion nebulosus),

323 Weakfish (Cynoscion regalis), and Whitemouth Croaker (Micropogonias furnieri). Notably,

324 growth of the Totoaba (Totoaba macdonaldi), a sciaenid closely related to Gulf Corvina and also

325 found in the Gulf of California, was modelled by the von Bertalanffy growth model. Growth of

326 the Gulf Corvina was modelled using the von Bertalanffy growth model in two previous studies.

327 Other growth models have been used to describe age and body length relationships in

328 sciaenids in 5 of $24(21 \%)$ the studies we reviewed. The Gompertz model was used to model

329 growth in female Spotted Seatrout. A linear model was used to model growth in male Spotted

330 Seatrout, although it was noted that the linear growth pattern may have been due to lack of

331 sampling of large and old individuals. Multi-model approaches similar to this study were

332 employed three times (13\%). One study on the Gulf Corvina selected the von Bertalanffy growth

333 model for two datasets, and the Schnute-Richards model for two other datasets. As such, this

334 study was counted in as one of the 20 studies that used the von Bertalanffy growth model to

335 model sciaenid growth, and as one of the five studies that employed other growth models. The

336 most recent age and growth study on Gulf Corvina selected the Schnute-Richards model, but did

337 not describe a biphasic growth pattern. The other study that employed multiple models fit them

338 to Spotted Seatrout age-length data and found the most statistical support for the three-parameter

339 logistic model.

Model selection

Synthesis of the above considerations and assessments led to the selection of the von

342 Bertalanffy growth model as the best model to represent Gulf Corvina growth. Of models fit in

343 this study, the von Bertalanffy growth model had the $4^{\text {th }}$ best statistical fit to raw data $($ AICc $=$ 
$3448813.66, \Delta \mathrm{AICc}=53.84, \mathrm{AICc}$ weight $=0 ; \mathrm{BIC}=8832.08, \Delta \mathrm{BIC}=44.66 ;$ Table 2$)$ and the

345 best statistical fit to raw data bolstered by simulated values (AICc $=18678.72, \Delta \mathrm{AICc}=0 . \mathrm{AICc}$

346 weight $=0.53 ; \mathrm{BIC}=18700.20, \Delta \mathrm{BIC}=0 ;$ Table 4). Of models fit in this study, the von

347 Bertalanffy growth model produced an $L_{\infty}$ closest to the $L_{\infty}$ predicted by Froese and Binohlan's

348 empirical relationship of $1006 \mathrm{~mm}$ (raw data: $916.05 \mathrm{~mm}$; raw data bolstered by simulated

349 values: $951.30 \mathrm{~mm}$; Tables 1 and 3). Further, the von Bertalanffy growth model was used to 350 represent sciaenid growth in $83 \%$ of studies reviewed.

351

352

353

354

355

356

357

358

359

360

361

362

363

364

365

366

\section{Simulations with a per-recruit model}

The current value of the exploitation rate of old adults of Gulf Corvina $\mathrm{E}_{\mathrm{OA}}$ that we estimated is $c a$. twice larger than the value of $\mathrm{E}_{\mathrm{OA}}$ at which the YPR of Gulf Corvina reaches a maximum, regardless of the growth model employed for simulations with the per-recruit model (Appendix S1). However, the current FNSSBR of Gulf Corvina predicted when using the Schnute-Richards growth model fit to raw data only $(0.60)$ is noticeably greater than the current FNSSBR of Gulf Corvina predicted when using all the other growth models (0.42-0.53) (Figure 6A). The value of fraction of natural SSBR that causes population collapse typically is in the range of 0.1-0.6 and lower for short-lived fish species such as Gulf Corvina (Myers et al., 1999; Grüss et al., 2014). Thus, the per-recruit model employing Schnute-Richards growth model predicts the Gulf Corvina stock to be in a much healthier state than the per-recruit models employing other growth models. The current YPR over $\mathrm{YPR}_{\max }$ of Gulf Corvina predicted when using the Schnute-Richards growth model fit to raw data only $(0.80)$ is also greater than the current YPR over YPR $_{\max }$ of Gulf Corvina predicted when using all the other growth models (0.70-0.74) (Figure 6B).

\section{Discussion}


This study illustrates the pitfalls of using statistical considerations alone when selecting a

368

369

370

371

372

373

374

375

376

377

378

380

381

382

383

384

385

386

387

388

389

growth model for a vulnerable and highly-exploited species, due to the high likelihood of a

biased distribution of samples. The combination of highly efficient, size-selective gear and high

fishing effort have altered the age structure of the Gulf Corvina population (Ortiz et al., 2016),

making sufficient representation of each size and age class difficult (Erisman et al., 2014). The

influence of the lack of large and old fish in the dataset used for this study is clear, as Froese and

Binohlan's (2000) empirical relationship predicted an $L_{\infty}$ that was $89.95-275.09 \mathrm{~mm}$ greater

than the $L_{\infty}$ predicted by growth modeled fit to raw data. This predicted $L_{\infty}$ from Froese and

Binohlan's (2000) empirical relationship of $1006 \mathrm{~mm}$ was identical to the $L_{\infty}$ estimated by

Gherard et al. (2013) with the von Bertalanffy growth model. Growth patterns (Figures 4 and 5)

and parameter estimates (Tables 1 and 3) were far less variable for models fit to data where

sample size was equal at age, compared to models fit to raw data alone.

Unfortunately, heavy exploitation of Gulf Corvina makes the use of biased data in age

and growth studies an unavoidable reality. Length data collected from the continuous monitoring

of the fishery (Erisman et al., 2015; Ortiz et al., 2016) indicate that Gulf Corvina may be able to

grow longer than their maximum reported length of $1013 \mathrm{~mm}$ and live longer than their

maximum reported age of 9 years, but heavy exploitation (exploitation rate of 0.825 year-1 for $^{-1}$

Gulf Corvina five years-old and older; Erisman et al. 2014) prevents them from doing so. Thus,

despite our best efforts, we were unable to sufficiently represent large and old fish in our dataset.

Further, while we made a concerted effort to sample small individuals, our data set would have

been improved if we were able to collect more. This led to our decision to employ our simulation

exercise to understand how the biases in our data affected our results. Similarly biased data have been the only data available for age and growth studies with Gulf Corvina, and previous studies 
390 have taken markedly different approaches to dealing with its limitations. Gherard et al. (2013)

391 chose to use the inflexible and widely comparable von Bertalanffy growth model while

392 acknowledging the data's limitations and caveating results accordingly. Alternatively, Aragón-

393 Noriega (2014) and Mendivil-Mendoza (2017) employed a multi-model approach that leaned

394 exclusively on statistics. Their statistical procedures led to the selection of the flexible Schnute-

395 Richards model to describe Gulf Corvina growth. Despite reporting different growth patterns

396 depending on which dataset was used, Aragón-Noriega (2014) did not acknowledge the

397 limitations of fishery-dependent data and concluded that Gulf Corvina grew in a biphasic pattern.

398

399

400

401

402

403

404

405

406

407

408

409

410

411

412
The same suite of models employed by Aragón-Noriega (2014) and Mendivil-Mendoza

et al. (2017) were fit to our data, and statistical measures of fit similarly supported the Schnute-

Richards model as the best model for Gulf Corvina. Further, a biphasic growth pattern was

described by the model, as it did in Aragón-Noriega's (2014) study. However, our review of 24

sciaenid growth studies indicated that only two (8\%) studies used the Schnute-Richards model to

describe sciaenid growth (Aragon-Noriega, 2014; Mendivil-Mendoza et al., 2017), of which only

one described biphasic growth (Aragón-Noriega, 2014). The biological implausibility of this

growth pattern was further supported by the distance between Froese and Binohlan's predicted

$L_{\infty}$ and the $L_{\infty}$ estimated by the Schnute-Richards model (1006 vs. $730.91 \mathrm{~mm}$, i.e., a $275.09 \mathrm{~mm}$

difference). Finally, simulating an ideal sampling scenario where each age class was equally

represented revealed that this biphasic growth pattern was due to bimodal distribution of samples

and a lack of large, old fish. Both the parameter estimates and growth pattern changed

substantially when simulated data was added to raw data so that sample size was equal for each

age (Figure 5 and Table 3). The Schnute-Richards model is flexible by design, and is, therefore, not suited for use with datasets that do not sufficiently represent each size and age class. Thus, 
413 by integrating the results of our statistical measures of fit, literature review, and simple indicators

414 of biased data, we selected the von Bertalanffy growth model as the best model to represent Gulf 415 Corvina growth.

417 each size and age class must be sufficiently represented for growth modelling to produce

418 biologically reasonable results (Cailliet et al., 1986; Cailliet and Tanaka, 1990; Francis and

419 Francis, 1992; Cailliet and Goldman, 2004). Ensuring sufficient representation may be difficult

420 for highly-exploited fishes, as exploitation alters the population structure of fishes by

421 preferentially selecting for large and old fish individuals (Berkeley et al., 2004; Mason, 1998).

422 Similar challenges are faced when studying growth for vulnerable fishes or in data-poor

423 fisheries, where there may not be resources available for extensive fishery-independent sampling

424 or fish are scarce in general. Despite difficulty, ensuring sufficient representation of each size

425 and age class should be a priority. The distinction between sampling to sufficiently represent

426 each size and age class and sampling to represent population structure is an important one to

427 make, as sampling to represent population structure should not be a goal of age and growth

428 studies due to the bias created by the natural scarcity of large and old fish. As such, the simple

429 simulation of an ideal sampling scenario with an equal number of samples at each age was not

430 intended to represent the population structure of Gulf Corvina or to reflect the relative

431 probability of obtaining samples of particular size and age classes in the real world. assessments for vulnerable and data-poor species (Fournier et al., 1990; Dulvy et al., 2004;

434 Froese, 2004; Honey et al., 2010; Hordyk et al., 2016). These types of assessments rely on age435 length data to determine vulnerability and overfishing, and problems emerge when all size and 
436 age classes are not sufficiently represented. The average maximum length $\left(L_{\infty}\right)$ is underestimated

437 and the growth rate $(K)$ is overestimated when large and old fish are absent. Accordingly, a short

438 generation time and lower levels of mortality are estimated, conferring more resilience to

439 exploitation that the population possesses (Campana, 2001; Goldman et al., 2012; Harry, 2017).

440 This idea was demonstrated with simulations with a per-recruit model, where the per recruit

441 model using the Schnute-Richards growth model fit to raw data (which had the lowest $L_{\infty}$ in the

442 present study) predicted Gulf Corvina reproductive capacity to be in a much healthier state than

443 the per recruit models using other growth models (Fig. 6A). This false resiliency makes fishery

444 management measures less effective (Campana, 2001; Cailliet and Andrews, 2008; Goldman et

445 al., 2012), and may be present in Gulf Corvina assessments, as length and age truncation in the

446 catch has increased progressively since biological monitoring of the fishery began in 1997

447 (Erisman et al., 2014). Given this length and age truncation, published growth models reported

448 for this species may not be representing biology but rather the influence of exploitation.

Our results have implications for estimating growth within a stock assessment. Piner

450 (2016) documented an increase in precision in parameter estimates, ability to account for

451 selectivity, and ability to incorporate multiple data sources when growth was estimated within a

452 stock assessment. However, the influence of sample distribution on model output should be

453 carefully examined if this approach is to be taken. So-called haphazard sampling strategies that

454 ensure that all age and size classes are represented (e.g. Wells et al., 2013) make growth

455 estimation within a stock assessment model more difficult, though are necessary if the density of

456 samples at a particular age is driving model fit or preventing accurate estimation of $\mathrm{L}_{\infty}$. Precision

457 may be improved, but care must be taken to ensure that precision is being improved around

458 biological reality. 

that is common among coastal fishes in the Gulf of California and other regions of the eastern

Pacific characterized by significant annual variations in precipitation, ocean temperatures, and

462 productivity in response to climate forcing that are known to influence growth rates in marine

463 fishes (e.g., El Niño Southern Oscillation, ENSO; (Wells et al., 2006; Williams et al., 2007;

464 Black, 2009). Specifically, growth rate is higher in Gulf Corvina during El Niño years, mainly in association with increased sea surface temperatures in the region (Reed, 2017). ENSO has been shown to affect fish growth in other areas, such as the waters of New Caledonia (Lehodey and

467 Grandperrin, 1996), New Zealand (Gillanders et al., 2012), and north-western Australia (Ong et al., 2016, 2015). As the present study was conducted over multiple years, it is reasonable to assume that variations in ENSO over the study period (i.e., a succession of El Niño/La Niña events) could have affected the fish harvested for this study, explaining the observed variation in length-at-age. These effects may affect estimates of growth derived with growth models, but in order to identify these effects with confidence, complete sampling must be conducted with this purpose in mind. Another explanation for length-at-age variation could be measurement error

474 (Neilson, 1992; Campana, 2001). Most of the fish in this study were harvested during their spawning season, which is around the time when they form new annuli. Therefore, it would be reasonable to conservatively assume that the precision of this study is more or less one year of 477 age. However, we have high confidence in our reading of these otoliths, as annuli are clearly 478 seen with minimal preparation (Figure 1) and we excluded any samples for which there was a 479 disagreement between readers. 
482 studies. Statistical measures of fit alone may not lead to the selection of a model that represents

483 biological reality (Wang et al., 1995; Cailliet et al., 2006; Araya and Cubillos, 2006). By

484 integrating measures of statistical fit with results from the simple indicators and literature review,

485 we concluded that the von Bertalanffy growth model best described the growth of Gulf Corvina

486 and was most appropriate for the quality of available data. Though the Schnute-Richards model

487 had the best statistical fit, it was not biologically reasonable, comparable between studies, or

488 robust to biased data. Simple indicators such as those described in this paper should be used to

489 reveal biases in data, and the use of flexible growth models such as the Schnute-Richards model

490 to represent the growth of Gulf Corvina and similarly exploited fishes should be halted if biases

491 are not accounted for.

492 Conclusions

493 Sample distribution influences growth model output, especially for flexible, statistically-driven

494 models. Data used in growth modelling studies should be thoroughly examined for bias, as

495 statistical measures of fit are insufficient for selecting a model that reflects biological reality.

496 Reflecting biological reality in growth models is critical for vulnerable fish and in data-poor

497 fisheries, where age-length data are integral to assessing vulnerability and overfishing. In this

498 case, the von Bertalanffy growth model represented biological reality best among the models

499 tested. We warn against the production and use of growth models without recognizing biases in

500 data given the serious implications for stock assessments and the management of vulnerable fish

501 populations and data-poor fisheries.

\section{Acknowledgements}


503 We acknowledge the Gulf of California Marine Program at Scripps Institution of Oceanography,

504 project participants from El Centro para la Biodiversidad Marina y la Conservacíon and the

505 fishers of the upper Gulf of California, Mexico for their contributions to data collection efforts.

506 We thank Gregor Cailliet for his pre-submission comments on the manuscript, Chip Cotton,

507 Brian Moe, and Grant Scholten for their feedback during data analysis, and Tyler Loughran for

508 her help with formatting figures.

\section{References}

Allen, L.G., Hovey, T.E., Love, M.S. and Smith, J.T., 1995. The life history of the spotted sand bass (Paralabrax maculatofasciatus) within the southern California bight. California Cooperative Oceanic Fisheries Investigations Report, 193-203.

Aragon-Noriega, E.A., 2014. Modeling the individual growth of the Gulf corvina, Cynoscion othonopterus (Pisces: Sciaenidae), using a multi-model approach. Cienc. Mar. 40, 149_ 161. https://doi.org/10.7773/cm.v40i2.2410

Araya, M., Cubillos, L.A., 2006. Evidence of two-phase growth in elasmobranchs. In Special Issue: Age and Growth of Chondrichthyan Fishes: New Methods, Techniques and Analysis, 293-300. Springer Netherlands.

Barbieri, L. R., Chittenden Jr, M. E., Jones, C. M., 1993. Age, growth, and mortality of Atlantic croaker, Micropogonias undulatus, in the Chesapeake Bay region, with a discussion of apparent geographic changes in population dynamics. Fish. Bull., 92(1).

Barger, L.E., 1985. Age and Growth of Atlantic Croakers in the Northern Gulf of Mexico, Based on Otolith Sections. Trans. Am. Fish. Soc., 114, 847-850. https://doi.org/10.1577/15488659(1985)114<847:AAGOAC>2.0.CO;2 
Baty, F., Ritz, C., Charles, S., Brutsche, M., Flandrois, J.P., Delignette-Muller, M.L., 2015. A Toolbox for Nonlinear Regression in R: The Package nlstools. J. of Stat. Soft., 66(5), 121. URL http://www.jstatsoft.org/v66/i05/.

Beckman, D. W., Fitzhugh, G. R., Wilson, C. A., 1988. Growth rates and validation of age estimates of red drum, Sciaenops ocellatus, in a Louisiana salt marsh impoundment. Cont. in Mar. Sci., 1988.

Berkeley, S.A., Hixon, M.A., Larson, R.J., Love, M.S., 2004. Fisheries Sustainability via Protection of Age Structure and Spatial Distribution of Fish Populations. Fisheries 29, 23-32. https://doi.org/10.1577/1548-8446(2004)29[23:FSVPOA]2.0.CO;2

Beverton, R.J.H. and Holt, S.J., 1957. On the dynamics of exploited fish populations. Fisheries Investigation Series 2, volume 19, UK Ministry of Agriculture. Fisheries, and Food, London, UK.

Black, B.A., 2009. Climate-driven synchrony across tree, bivalve, and rockfish growthincrement chronologies of the northeast Pacific. Mar. Ecol. Prog. Ser. 378, 37-46. https://doi.org/10.3354/meps07854

Brunel, T., Dickey-Collas, M., 2010. Effects of temperature and population density on von Bertalanffy growth parameters in Atlantic herring:: a macro-ecological analysis. Mar. Ecol. Prog. Ser. 405, 15-28.

Burnham, K.P., Anderson, D.R., 2004. Multimodel Inference: Understanding AIC and BIC in Model Selection. Sociol. Methods Res. 33, 261-304. https://doi.org/10.1177/0049124104268644 
Cailliet, G.M. and Andrews, A.H., 2008. Age-validated longevity of fishes: its importance for sustainable fisheries. Fisheries for Global Welfare and Environment (Eds K. Tsukamoto, T. Kawamura, T. Takeuchi, TD Beard, Jr. and MJ Kaiser), 103-120.

Cailliet, G.M., Botsford, L.W., Brittnacher, J.G., Ford, G., Matsubayashi, M., King, A., Watters, D.L. and Kope, R.G., 1996. Development of a computer-aided age determination system: evaluation based on otoliths of bank rockfish off California. Trans. Am. Fish. Soc., $125(6), 874-888$.

Cailliet, G.M.L., Ebeling, M.S., Cailliet, A.W.G.M., Love, M.S. and Ebeling, A.W., 1986. Fishes: a field and laboratory manual on their structure, identification, and natural history (No. C/597.04 C3).

Cailliet, G.M. and Goldman, K.J., 2004. Age Determination and Validation in Chondrichthyan Fishes, Chapter 14, pages 399-447, in: Carrier, J., J.A. Musick, and M. R. Heithaus (Editors), Biology of Sharks and Their Relatives. CRC Press LLC, Boca Raton, Florida. Cailliet, G.M., Smith, W.D., Mollet, H.F., and Goldman, K.J., 2006. Age and growth studies of chondrichthyan fishes: the need for consistency in terminology, verification, validation, and growth function fitting. Env. Biol. of Fish., 77: 211-228.

Cailliet, G. M. and Tanaka, S., 1990. Recommendations for research needed to better understand the age and growth of elasmobranchs, in Elasmobranchs as Living Resources: Advances in the Biology, Ecology, Systematics, and the Status of the Fisheries, W.S. Pratt, Jr., S. H. Gruber, and T. Taniuchi, Eds., NOAA Tech. Rep. 90:505-507.

Campana, S.E., 2001. Accuracy, precision and quality control in age determination, including a review of the use and abuse of age validation methods. J. Fish Biol. 59, 197-242. https://doi.org/10.1111/j.1095-8649.2001.tb00127.x 
Chao, L., Espinosa, H., Findley, L., van der Heiden, A., 2010. Cynoscion othonopterus. in: IUCN 2012. IUCN Red List of Threatened Species. Version 2012.2. www.iucnredlist.org (downloaded on 20 September 2017).

Chen, Y., Jackson, D.A., Harvey, H.H., 1992. A Comparison of von Bertalanffy and Polynomial Functions in Modelling Fish Growth Data. Can. J. Fish. Aquat. Sci. 49, 1228-1235. https://doi.org/10.1139/f92-138

Clardy, S.D., Brown-Peterson, N.J., Peterson, M.S., Leaf, R.T., 2014. Age, growth, and reproduction of Southern Kingfish (Menticirrhus americanus): a multivariate comparison with life history patterns in other sciaenids. Fish. Bull. 112, 178-197. https://doi.org/10.7755/FB.112.2-3.6

Cottrell, S. A., 1990. Age and growth of spotted seatrout in the Indian River Lagoon, Florida. Master's thesis. University of Central Florida, Orlando.

Czarnołe‘ski, M. and Kozłowski, J., 1998. Do Bertalanffy's growth curves result from optimal resource allocation? Ecol. Let., 1(1), 5-7.

Dippold, D.A., Leaf, R.T., Hendon, J.R., Franks, J.S., 2016. Estimation of the Length-at-Age Relationship of Mississippi’s Spotted Seatrout. Trans. Am. Fish. Soc. 145, 295-304. https://doi.org/10.1080/00028487.2015.1121926

Dulvy, N.K., Ellis, J.R., Goodwin, N.B., Grant, A., Reynolds, J.D., Jennings, S., 2004. Methods of assessing extinction risk in marine fishes. Fish Fish. 5, 255-276. https://doi.org/10.1111/j.1467-2679.2004.00158.x

Elzhov, T. V., Mullen, K. M., Spiess, A.-N., Bolker, B., Mullen, M. K. M., 2015. Package 'minpack. lm'; CRAN Repository. 
Erisman, B., Aburto-Oropeza, O., Gonzalez-Abraham, C., Mascareñas-Osorio, I., Moreno-Báez, M., Hastings, P.A., 2012. Spatio-temporal dynamics of a fish spawning aggregation and its fishery in the Gulf of California. Sci. Rep. 2, srep00284. https://doi.org/10.1038/srep00284

Erisman, B.E., Apel, A.M., MacCall, A.D., Román, M.J., Fujita, R., 2014. The influence of gear selectivity and spawning behavior on a data-poor assessment of a spawning aggregation fishery. Fish. Res. 159, 75-87. https://doi.org/10.1016/j.fishres.2014.05.013

Erisman, B., Mascareñas, I., Lopez-Sagastegui, C., Moreno-Baez, M., Jimenez-Esquivel, V., Aburto-Oropeza, O., 2015. A comparison of fishing activities between two coastal communities within a biosphere reserve in the Upper Gulf of California., Fish. Res. $164: 254-265$

Fournier, D.A., Sibert, J.R., Majkowski, J., Hampton, J., 1990. MULTIFAN a Likelihood-Based Method for Estimating Growth Parameters and Age Composition from Multiple Length Frequency Data Sets Illustrated using Data for Southern Bluefin Tuna (Thunnus maccoyii). Can. J. Fish. Aquat. Sci. 47, 301-317. https://doi.org/10.1139/f90-032

Francis, M. P. and Francis, R. I. C. C., 1992. Growth rate estimates for New Zealand rig (Mustelus lenticulatus). Aust. J. Mar. Freshwater Res.43:1157-1176.

Francis, R.I.C.C., 2016. Growth in age-structured stock assessment models. Fish. Res., Growth: theory, estimation, and application in fishery stock assessment models 180, 77-86. https://doi.org/10.1016/j.fishres.2015.02.018

Franco, D.M., 2014. Determining life history characteristics of Atlantic croaker, Micropogonias undulatus, within coastal Georgia waters. Master's Thesis, Savannah State University. 
Froese, R., 2004. Keep it simple: three indicators to deal with overfishing. Fish Fish. 5, 86-91. https://doi.org/10.1111/j.1467-2979.2004.00144.x

Froese, R., Binohlan, C., 2000. Empirical relationships to estimate asymptotic length, length at first maturity and length at maximum yield per recruit in fishes, with a simple method to evaluate length frequency data. J. Fish Biol. 56, 758-773. doi:10.1111/j.10958649.2000.tb00870.x.

Gallucci II, V.F., Quinn, T.J., 1979. Reparameterizing, Fitting, and Testing a Simple Growth Model. Trans. Am. Fish. Soc. 108, 14-25. https://doi.org/10.1577/15488659(1979)108<14:RFATAS $>2.0 . \mathrm{CO} ; 2$

Gherard, K.E., Erisman, B.E., Aburto-Oropeza, O., Rowell, K., Allen, L.G., 2013. Growth, development, and reproduction in Gulf corvina (Cynoscion othonopterus). Bull. South. Calif. Acad. Sci. 112, 1-18.

Gillanders, B.M., Black, B.A., Meekan, M.G., Morrison, M.A., 2012. Climatic effects on the growth of a temperate reef fish from the Southern Hemisphere: a biochronological approach. Mar. Biol. 159, 1327-1333. https://doi.org/10.1007/s00227-012-1913-x

Goldman, K.J., Cailliet, G.M., Andrews, A.H., and Natanson, L.J., 2012. Assessing the Age and Growth of Chondrichthyan Fishes. Chapter 14, 423-452 in: Carrier, J., J.A. Musick, and M. R. Heithaus (Editors), Biology of Sharks and Their Relatives, Second Edition. CRC Press LLC, Boca Raton, Florida.

Gompertz, B., 1825. On the Nature of the Function Expressive of the Law of Human Mortality, and on a New Mode of Determining the Value of Life Contingencies. Philos. Trans. R. Soc. Lond. 115, 513-583. 
Grüss, A., Kaplan, D.M., Robinson, J., 2014. Evaluation of the effectiveness of marine reserves for transient spawning aggregations in data-limited situations. ICES J. of Mar. Sci., 71, $435-449$.

Hatch, J., Jiao, Y., 2016. A comparison between traditional and measurement-error growth models for weakfish Cynoscion regalis. PeerJ 4, e2431. https://doi.org/10.7717/peerj.2431

Harry, A.V., 2017. Evidence for systemic age underestimation in shark and ray ageing studies. Fish Fish. 00,1-16. doi:10.1111/faf.12243.

Helser, T.E., Lai, H.-L., 2004. A Bayesian hierarchical meta-analysis of fish growth: with an example for North American largemouth bass, Micropterus salmoides. Ecol. Model. 178, 399-416. https://doi.org/10.1016/j.ecolmodel.2004.02.013

Honey, K.T., Moxley, J.H., Fujita, R.M., 2010. From rags to fishes: data-poor methods for fishery managers. Managing Data-Poor Fisheries: Case Studies, Models and Solutions, vol. 1, pp. 159-184 (California Sea Grant College Program).

Hordyk, A.R., Ono, K., Prince, J.D., Walters, C.J., 2016. A simple length-structured model based on life history ratios and incorporating size-dependent selectivity: application to spawning potential ratios for data-poor stocks. Can. J. Fish. Aquat. Sci. 73, 1787-1799. https://doi.org/10.1139/cjfas-2015-0422

Kimura, D.K., 2008. Extending the von Bertalanffy growth model using explanatory variables. Can. J. Fish. Aquat. Sci. 65, 1879-1891. https://doi.org/10.1139/F08-091

Lehodey, P., Grandperrin, R., 1996. Influence of temperature and ENSO events on the growth of the deep demersal fish alfonsino, Beryx splendens, off New Caledonia in the western 
tropical South Pacific Ocean. Deep Sea Res. Part Oceanogr. Res. Pap. 43, 49-57. https://doi.org/10.1016/0967-0637(95)00096-8

Lorenzen, K., 2016. Toward a new paradigm for growth modeling in fisheries stock assessments: Embracing plasticity and its consequences. Fish. Res., Growth: theory, estimation, and application in fishery stock assessment models 180, 4-22. https://doi.org/10.1016/j.fishres.2016.01.006

Lowerre-Barbieri, S.K., Chittenden, M.E. and Barbieri, L.R., 1995. Age and growth of weakfish, Cynoscion regalis, in the Chesapeake Bay region with a discussion of historical changes in maximum size. Fish. Bull., 93(4), 643-656.

Maceina, M.J., Hata, D.N., Linton, T.L., Landry, A.M., 1987. Age and Growth Analysis of Spotted Seatrout from Galveston Bay, Texas. Trans. Am. Fish. Soc. 116, 54-59. https://doi.org/10.1577/1548-8659(1987)116<54:AAGAOS>2.0.CO;2

MacLennan, D.N., 1992. Fishing gear selectivity: an overview. Fish. Res., Fishing Gear Selectivity 13, 201-204. https://doi.org/10.1016/0165-7836(92)90076-6

Manickchand-Heileman, S.C. and Kenny, J.S., 1990. Reproduction, age, and growth of the whitemouth croaker Micropogonias furnieri (Desmarest 1823) in Trinidad waters. Fish. Bull., 88(3), 523-529.

Mason, J.E., 1998. Declining Rockfish Lengths in the Monterey Bay, California, Recreational Fishery, 1959-94. Mar. Fish. Rev. 60, 15-28.

Mazerolle, M.J. 2017. AICcmodavg: Model selection and multimodel inference based on (Q)AIC(c). R package version 2.1-1. https://cran.r-project.org/package=AICcmodavg. Mendivil-Mendoza, J.E., Rodríguez-Domínguez, G., Castillo-Vargasmachuca, S.G., OrtegaLizárraga, G.G., Aragón-Noriega, E.A., 2017. ESTIMACIÓN DE LOS PARÁMETROS 
DE CRECIMIENTO DE LA CURVINA GOLFINA Cynoscion othonopterus (PISCES: SCIAENIDAE) POR MEDIO DE LOS CASOS DEL MODELO DE SCHNUTE. Interciencia 42.

Murphy, M.D., and Taylor, R.G., 1989. Reproduction and growth of black drum, Pogonias cromis, in Northeast Florida. Northeast Gulf Sci. 10 (2).

Murphy, M.D., Taylor, R.G., 1990. Reproduction, growth, and mortality of red drum Sciaenops ocellatus in Florida waters. Fish. Bull.

Murphy, M.D., Taylor, R.G., 1994. Age, Growth, and Mortality of Spotted Seatrout in Florida Waters. Trans. Am. Fish. Soc., 123, 482-497. https://doi.org/10.1577/15488659(1994)123<0482:AGAMOS>2.3.CO;2

Myers, R.A., Bowen, K.G., Barrowman, N.J., 1999. Maximum reproductive rate of fish at low population sizes. Can. J. Fish. Aquat. Sci., 56, 2404-2419.

Neilson, J.D., 1992. Sources of error in otolith microstructure examination, p. 115-125. In D.K. Stevenson and SE. Campana [ed.]. Otolith microstructure examination and analysis. Can. Spec. Pub. of Fish. and Aquat. Sci. 117.

Nieland, D.L., Thomas, R.G., Wilson, C.A., 2002. Age, Growth, and Reproduction of Spotted Seatrout in Barataria Bay, Louisiana. Trans. Am. Fish. Soc., 131, 245-259. https://doi.org/10.1577/1548-8659(2002)131<0245:AGAROS>2.0.CO;2

Ogle, D.H., 2017. FSA: Fisheries Stock Analysis. R package version 0.8.16.

Ong, J.J.L., Nicholas Rountrey, A., Jane Meeuwig, J., John Newman, S., Zinke, J., Gregory Meekan, M., 2015. Contrasting environmental drivers of adult and juvenile growth in a marine fish: implications for the effects of climate change. Sci. Rep. 5, 10859. https://doi.org/10.1038/srep10859 
Ong, J.J.L., Rountrey, A.N., Zinke, J., Meeuwig, J.J., Grierson, P.F., O’Donnell, A.J., Newman, S.J., Lough, J.M., Trougan, M., Meekan, M.G., 2016. Evidence for climate-driven synchrony of marine and terrestrial ecosystems in northwest Australia. Glob. Change Biol. 22, 2776-2786. https://doi.org/10.1111/gcb.13239

Ortiz, R., Mascareñas-Osorio, I., Román, M., Castro, J., 2016. Biological and fisheries monitoring of the Gulf Corvina in the Upper Gulf of California. DataMares. Interactive Resource. http://doi.org/10.13022/M38590

Pauly, D., 2010. Gasping Fish and Panting Squids: Oxygen, Temperature and the Growth of Water Breathing Animals. O. Kinne (editor). 2010. International Ecology Institute. Excellence in Ecology: Book 22. 216 p.

Piner, K.R., Lee, H.-H., Maunder, M.N., 2016. Evaluation of using random-at-length observations and an equilibrium approximation of the population age structure in fitting the von Bertalanffy growth function. Fish. Res., Growth: theory, estimation, and application in fishery stock assessment models 180, 128-137. doi:10.1016/j.fishres.2015.05.024.

Punt, A.E., Haddon, M., McGarvey, R., 2016. Estimating growth within size-structured fishery stock assessments: What is the state of the art and what does the future look like? Fish. Res., Growth: theory, estimation, and application in fishery stock assessment models 180, 147-160. https://doi.org/10.1016/j.fishres.2014.11.007

Ratkowsky, D.A., 1986. Statistical Properties of Alternative Parameterizations of the von Bertalanffy Growth Curve. Can. J. Fish. Aquat. Sci. 43, 742-747. https://doi.org/10.1139/f86-091 
Reed, E., 2017. Relationships between climate, growth and fisheries production in a commercially exploited marine fish. Master's Thesis, The University of Texas at Austin.

Ricker, W. E., 1975. Computation and interpretation of biological statistics of fish populations. Bull. Fish. Res. Board Can., 191 (1975), pp. 1-382.

Robertson, D.R., Allen, G.R., 2008. Shorefishes of the Tropical Eastern Pacific online information system. Version 1.0. Smithsonian Tropical Research Institute, Balboa, Panama.

Rodriguez, R. and Hammann, M.G., 1997. Age and growth of totoaba, Totoaba macdonaldi (Sciaenidae), in the upper Gulf of California. Fish. Bull., 95(3), 620-628.

Roff, D.A., 1980. A Motion for the Retirement of the Von Bertalanffy Function. Can. J. Fish. Aquat. Sci. 37, 127-129. https://doi.org/10.1139/f80-016

Román-Rodríguez, M.J., 2000. Estudio poblacional del chano norteño, Micropogonias megalops y la curvina Golfina Cynoscion othonopterus (Gilbert) (Pisces: Sciaenidae), especies endémicas del alto Golfo California, Mexico. Instituto del Medio Ambiente y Desarrollo Sustentable del Estado de Sonora. Informe final SNIB-CONABIO proyecto No. L298. Mexico, D.F. www.conabio.gob.mx/institucion/cgi$\underline{\text { bin/datos.cgi? } \text { Letras }=\text { L } \& \text { Numero }=298}$.

Ross, J.L., Stevens, T.M., Vaughan, D.S., 1995. Age, Growth, Mortality, and Reproductive Biology of Red Drums in North Carolina Waters. Trans. Am. Fish. Soc. 124, 37-54. https://doi.org/10.1577/1548-8659(1995)124<0037:AGMARB>2.3.CO;2

Rowell K., Flessa, K.W., Dettman, D.L., Roman M., 2005. The importance of Colorado River flow to nursery habitats of the Gulf Corvina (Cynoscion othonopterus). Can. J. Fish. Aquat. Sci., 62, 2874-2885. 
Ruelas-Peña, J.H., Valdez-Muñoz, C., and Aragón-Noriega, E., 2013. La pesquería de la corvina golfina y las acciones de manejo en el Alto Golfo de California, México. Lat. Amer. J. Aquat. Res., 41. 498-505.

Rutherford, E.S., Thue, E.B. and Buker, D.G., 1982. Population Characteristics, Food Habits and Spawning Activity of Spotted Seatrout, Cynoscion Nebulosis, in Everglades National Park, Florida. National Park Service, South Florida Research Center, Everglades National Park

Sampson, D.B., 2014. Fishery selection and its relevance to stock assessment and fishery management. Fish. Res., SI: Selectivity 158, 5-14. https://doi.org/10.1016/j.fishres.2013.10.004

Santos, R.S., Costa, M.R. da, Araújo, F.G., Santos, R.S., Costa, M.R. da, Araújo, F.G., 2017. Age and growth of the white croaker Micropogonias furnieri (Perciformes: Sciaenidae) in a coastal area of Southeastern Brazilian Bight. Neotrop. Ichth. 15. https://doi.org/10.1590/1982-0224-20160131

Schnute, J., 1981. A Versatile Growth Model with Statistically Stable Parameters. Can. J. Fish. Aquat. Sci. 38, 1128-1140. https://doi.org/10.1139/f81-153

Schnute, J.T., Richards, L.J., 1990. A Unified Approach to the Analysis of Fish Growth, Maturity, and Survivorship Data. Can. J. Fish. Aquat. Sci. 47, 24-40. https://doi.org/10.1139/f90-003

Schwarz, G., 1978. Estimating the dimension of a model. The Ann. of Stat., 6(2), 461-464.

Shono, H., 2000. Efficiency of the finite correction of Akaike's information criteria. Fish. Sci., 66(3), 608-610. 
van Poorten, B.T., Walters, C.J., 2016. How can bioenergetics help us predict changes in fish growth patterns? Fish. Res., Growth: theory, estimation, and application in fishery stock assessment models 180, 23-30. https://doi.org/10.1016/j.fishres.2015.07.031

von Bertalanffy, L., 1938. A quantitative theory of organic growth (inquiries on growth laws II). Hum. Biol., 10, 181-213.

Walker, T.I., Taylor, B.L., Hudson, R.J., Cottier, J.P., 1998. The phenomenon of apparent change of growth rate in gummy shark (Mustelus antarcticus) harvested off southern Australia. Fish. Res. 39(2), 139-63.

Wang, Y.G., Thomas, M.R., Somers, I.F., 1995. A maximum likelihood approach for estimating growth from tag-recapture data. Can. J. Fish. Aquat. Sci. 52(2), 252-259.

Weatherley, A.H., 1990. Approaches to Understanding Fish Growth. Trans. Am. Fish. Soc. 119, 662-672. https://doi.org/10.1577/1548-8659(1990)119<0662:ATUFG>2.3.CO;2

Wells, B.K., Grimes, C.B., Field, J.C., Reiss, C.S., 2006. Covariation between the average lengths of mature coho (Oncorhynchus kisutch) and Chinook salmon (O. tshawytscha) and the ocean environment. Fish. Oceanogr. 15, 67-79. https://doi.org/10.1111/j.13652419.2005.00361.x

Wells, R.J.D., Kohin, S., Teo, S.L.H., Snodgrass, O.E., Uosaki, K., 2013. Age and growth of North Pacific albacore (Thunnus alalunga): Implications for stock assessment. Fish. Res. 147, 55-62. https://doi.org/10.1016/j.fishres.2013.05.001

White, A.L., 2017. Spatial and temporal heterogeneity in life history and productivity trends of Atlantic Weakfish (Cynoscion regalis) and implications to fisheries management. Master's Thesis, Virginia Tech. 
Wieting, D. S., 1989. Age, growth, and fecundity of spotted seatrout (Cynoscion nebulosus) in Louisiana. Master's thesis. Louisiana State University, Baton Rouge.

Williams, J.P., Allen, L.G., Steele, M.A., Pondella, D.J., 2007. El Niño periods increase growth of juvenile white seabass (Atractoscion nobilis) in the Southern California Bight. Mar. Biol., 152, 193-200. 


\section{Figure 1}

Transverse section of a sagittal otolith from a five-year old Gulf Corvina

Annuli are numbered and marked by white rectangles. Transmitted light under a Zeiss Stemi 2000-C microscope with a Zeiss Axiocam 105 color camera at 6.25x total magnification was used to count the alternating opaque and translucent growth zones that define an annulus.

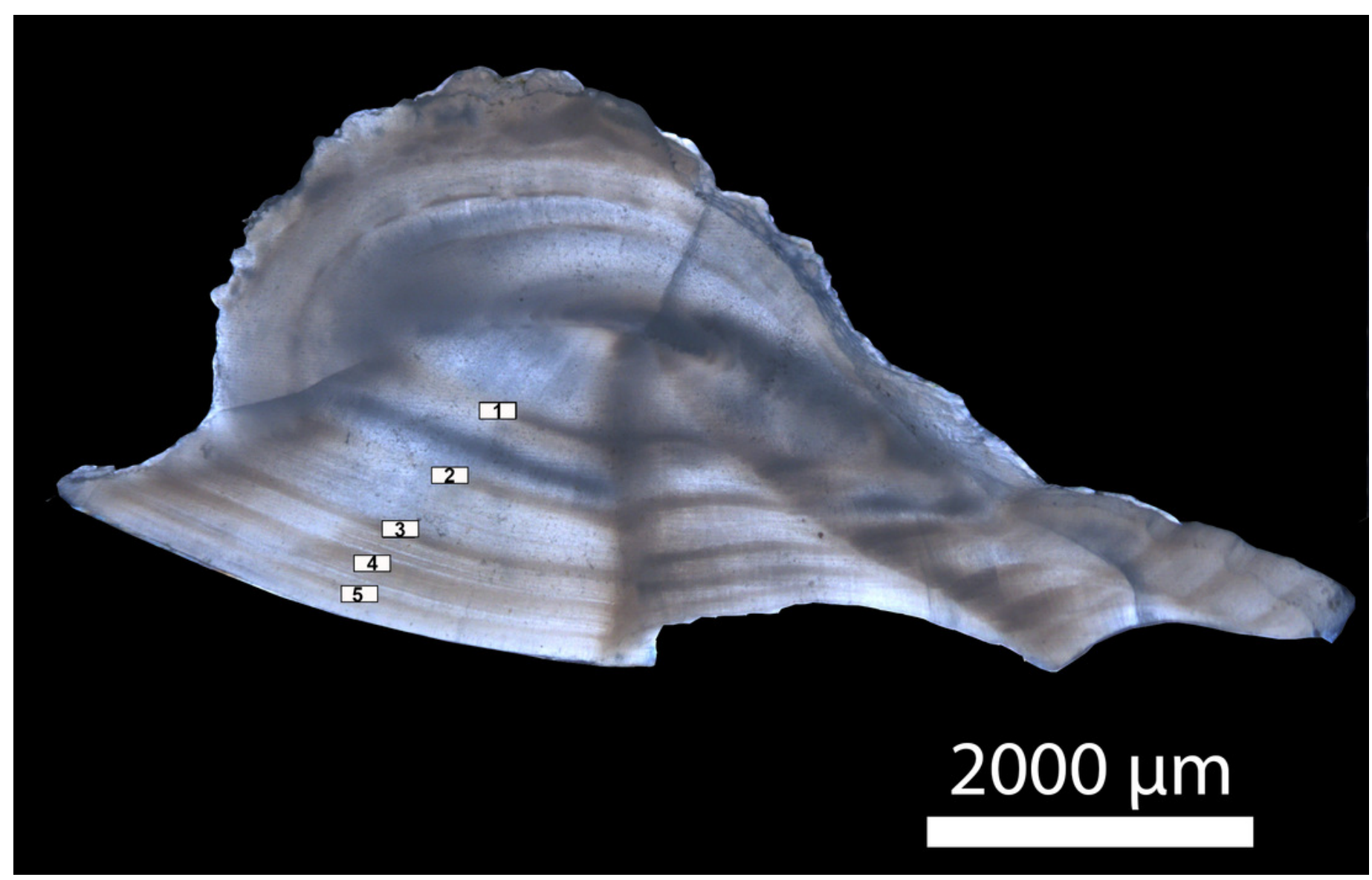




\section{Figure 2}

Length frequency of Gulf Corvina from raw data represented in $10 \mathrm{~mm}$ bins

A bimodal distribution is observed, with the first consisting of Gulf Corvina caught as bycatch, and the second largely consisting of fish from the directed fishery. Few fish larger than 750 $\mathrm{mm}$ are present in this dataset.

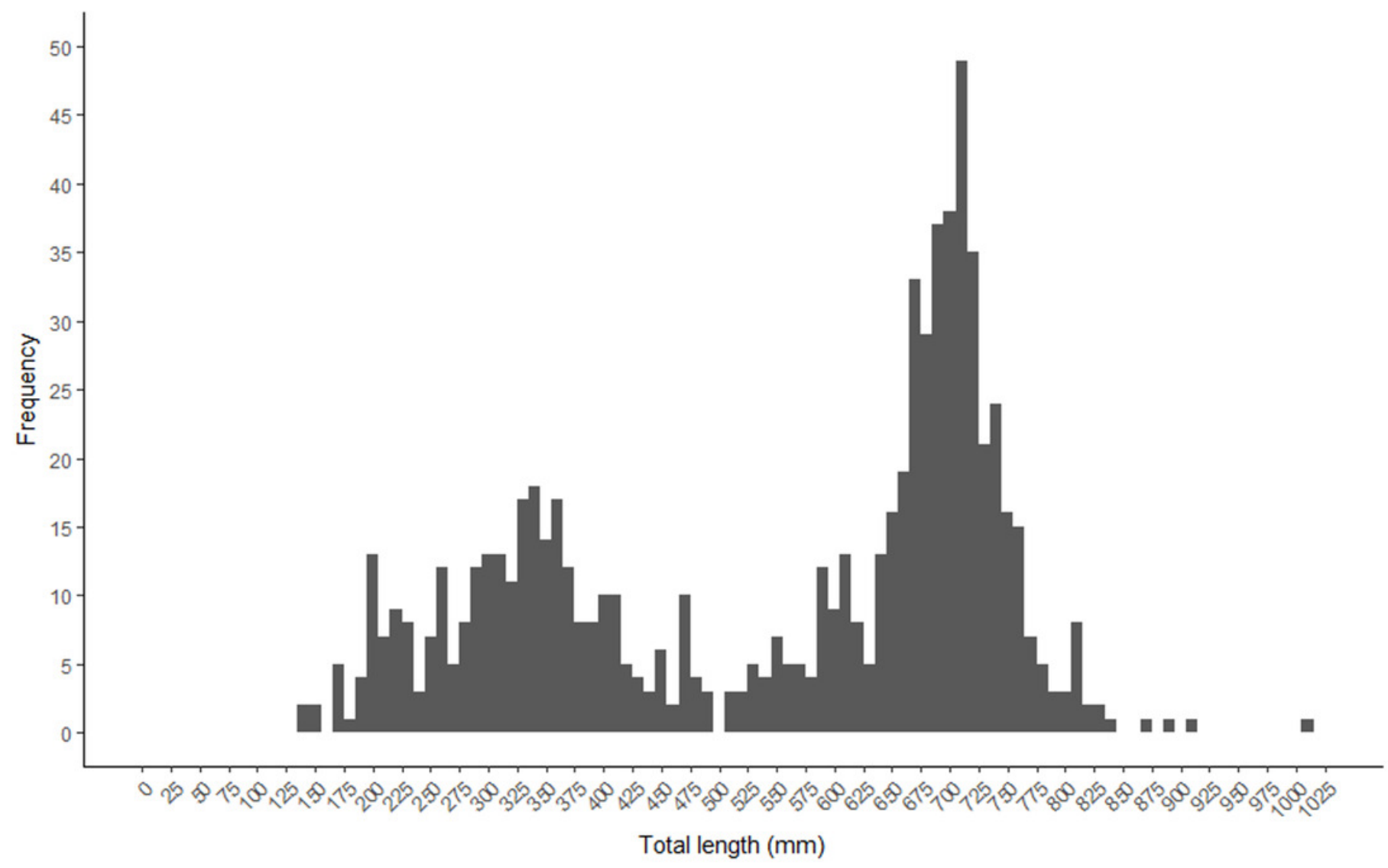




\section{Figure 3}

Age frequency of Gulf Corvina from raw data

A bimodal distribution is observed, with the first consisting of Gulf Corvina caught as bycatch, and the second largely consisting of fish from the directed fishery. Few fish older than age 6 are present in this dataset.

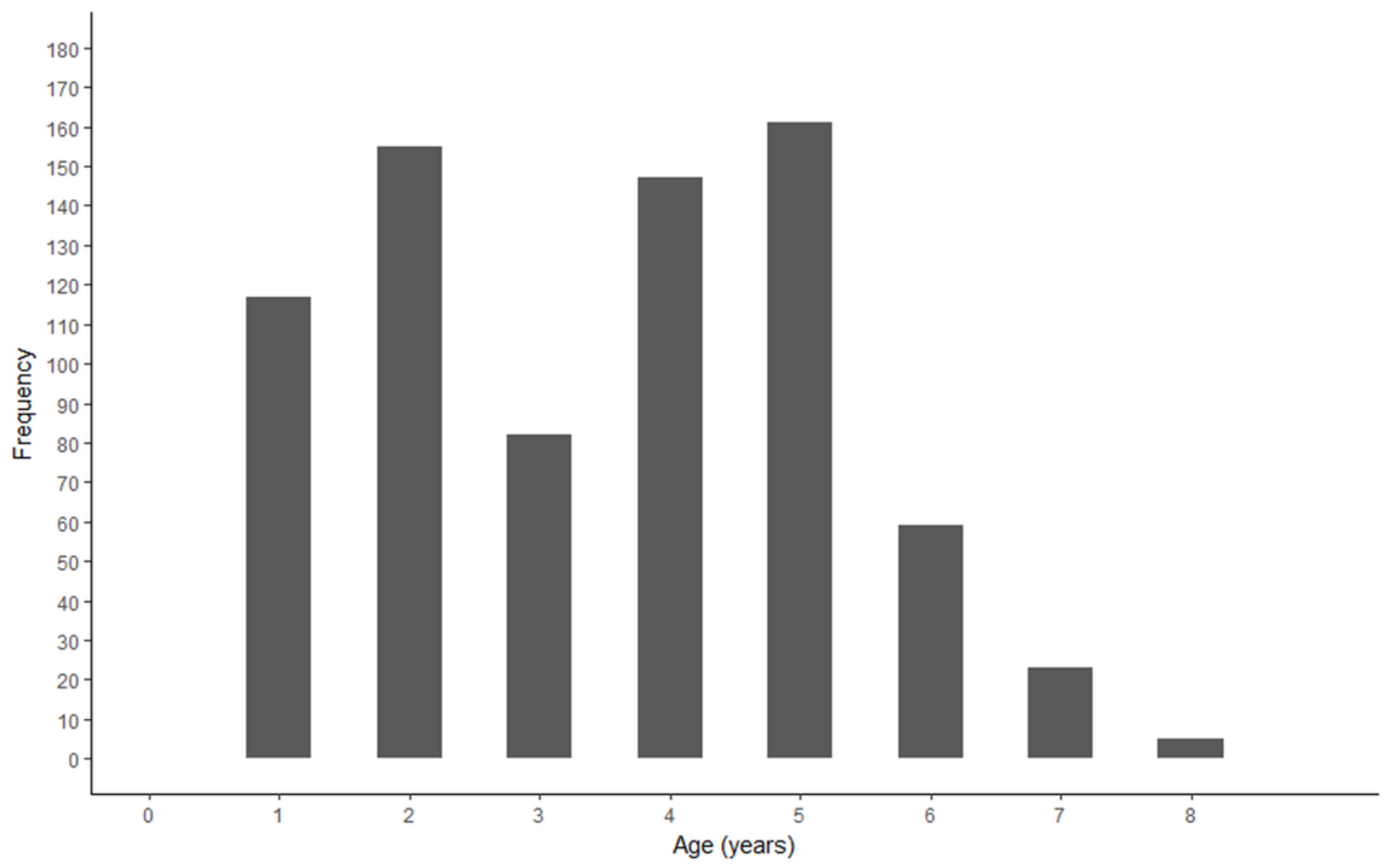


Figure 4

Growth models fit to raw age-length data for Gulf Corvina

The Gompertz, Logistic, and von Bertalanffy models yield asymptotic growth patterns.

However, the Schnute-Richards model describes bi-phasic growth, and the Schnute model describes near-linear growth after the first 1.5 years of life. Differences in modelled size at age are most pronounced at the beginning and end of life, where samples are most scarce.

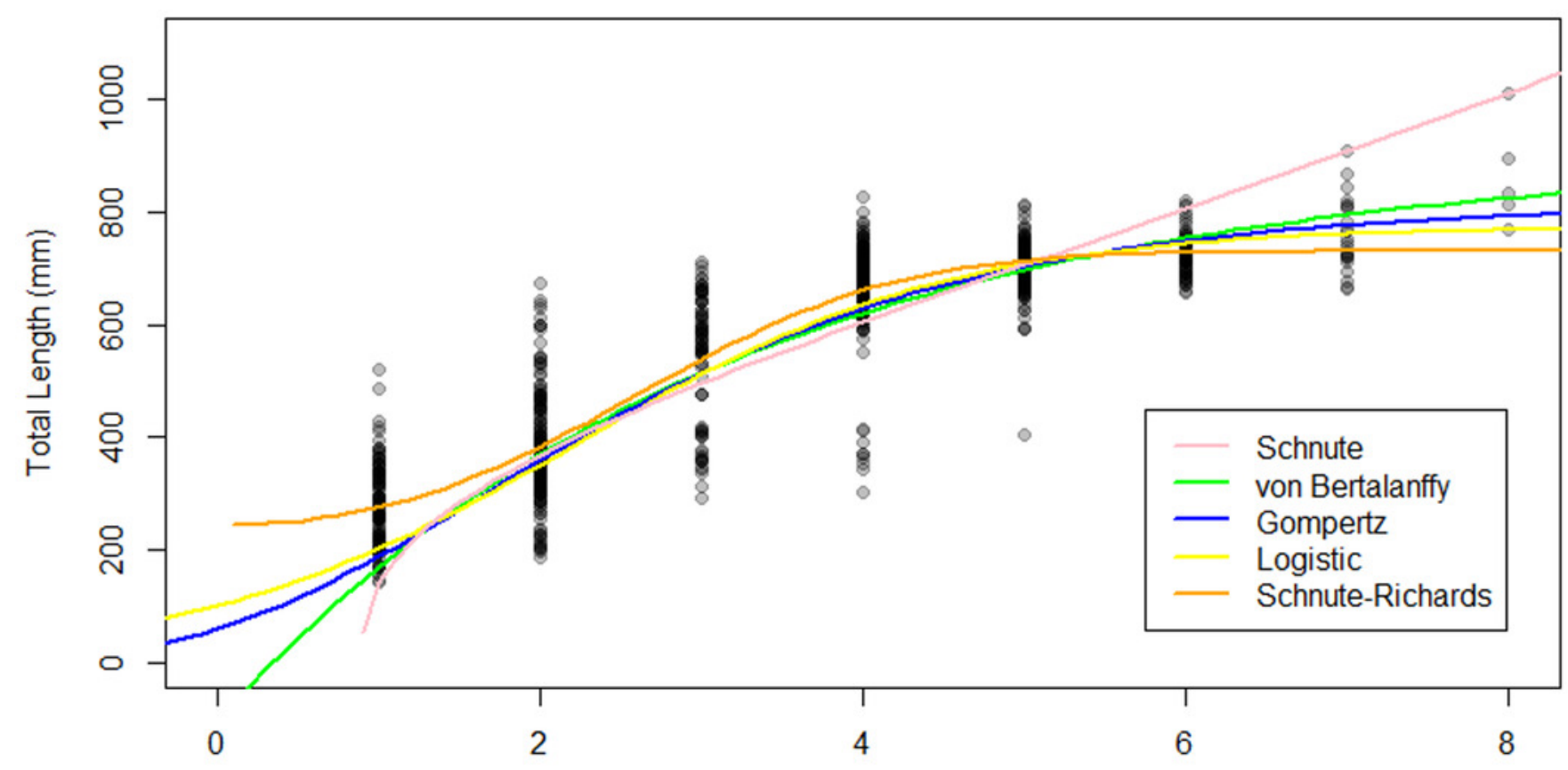

Age (years) 
Figure 5

Growth models fit to raw Gulf Corvina age-length data bolstered by simulated values

All models except for the Schnute describe asymptotic growth, and only show slight differences in modelled size at age. Differences in modelled size at age are most pronounced at the beginning and end of life.

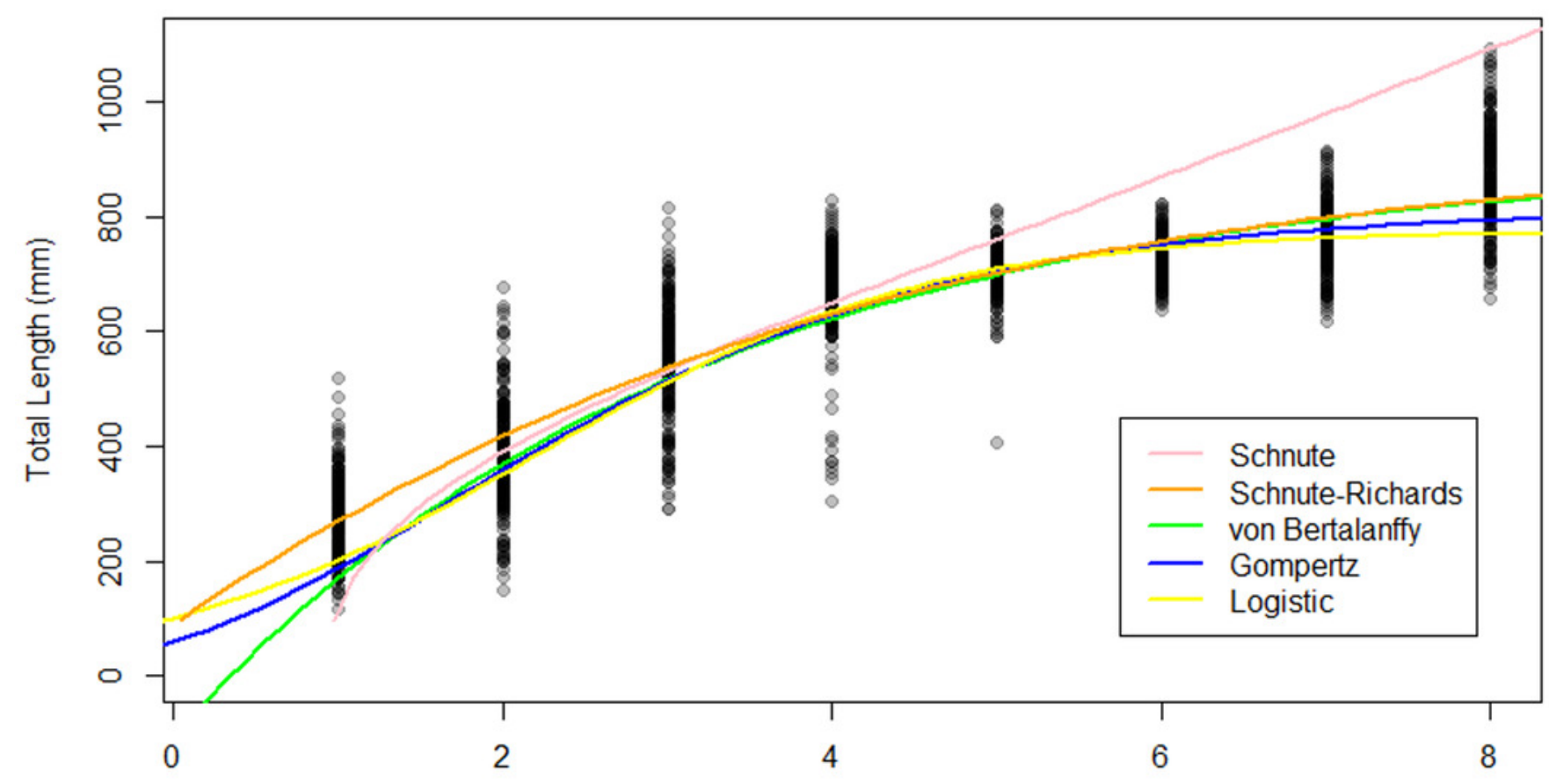

Age (years) 


\section{Figure 6}

Consequences of using different growth models on $(A)$ the current female SSBR over

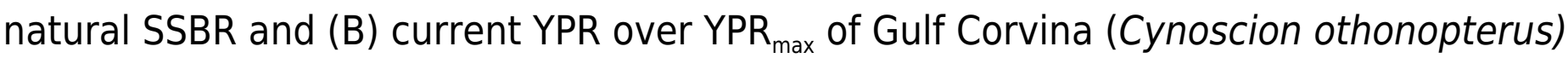

SSBR $=$ spawning-stock-biomass-per-recruit. YPR $=$ yield-per-recruit. Gherard model $=$ von Bertalanffy model developed in Gherard et al. (2013). VB model = von Bertalanffy model fit to raw data in the present study. VB bolstered model $=$ von Bertalanffy model fit to raw data bolstered by simulation values in this study. S-R model = Schnute-Richards model fit to raw data in the present study. S-R bolstered model $=$ Schnute-Richards model fit to raw data bolstered by simulation values in this study.

(A)

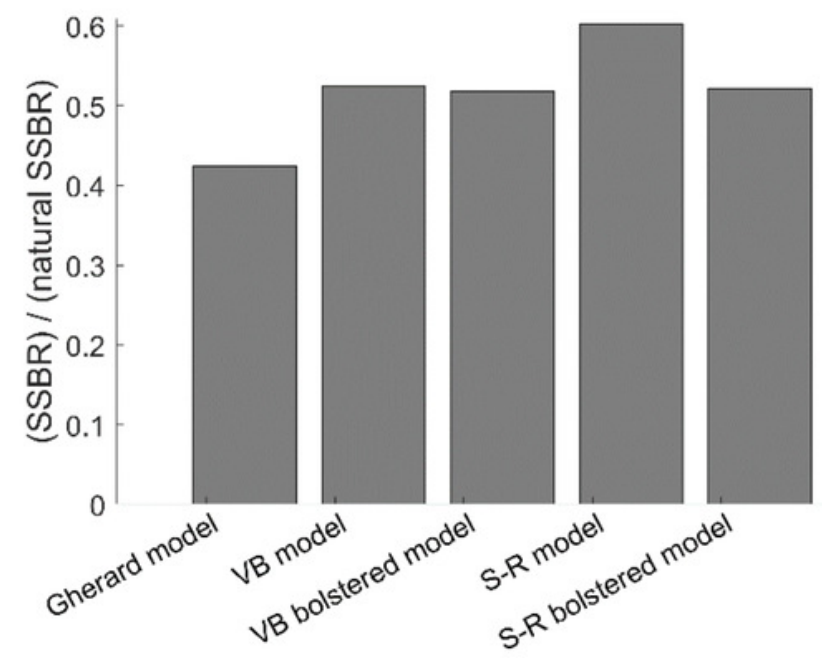

(B)

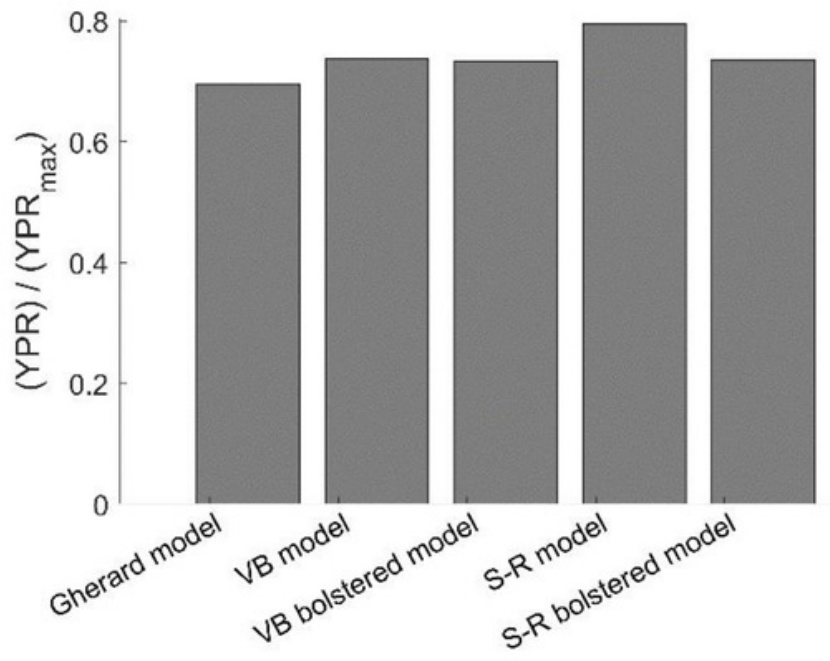




\section{Table $\mathbf{1}$ (on next page)}

Parameter estimates for growth models fit to raw age-length data for Gulf Corvina

Estimates of $L_{\infty}$ are variable, but not as variable as those reported in previous multi-model studies of Gulf Corvina growth (Aragón-Noriega, 2014; Mendivil-Mendoza, 2017). Confidence intervals around parameter estimates may be found in the supplemental information. 


\begin{tabular}{|c|c|c|c|}
\hline Model name & & Model equation when fit to raw data & \\
\hline von Bertalanffy & & $L(t)=916.05\left[1-e^{-0.28(t-(-0.17))}\right]$ & \\
\hline Gompertz & & $L(t)=820.64 e^{\left(-\left(\frac{1}{0.51}\right) e^{-0.51(t-1.29)}\right)}$ & \\
\hline Logistic & & $L(t)=778.88\left[1+e^{-0.76(t-1.92)}\right]^{-1}$ & \\
\hline Schnute & $L(t)=$ & {$\left[141^{-0.33}+\left(1013^{-0.33}-141^{-0.33}\right) \frac{1-e^{-3.36(t-1)}}{1-e^{-3.36(8-1)}}\right]$} & $1 /-0.33$ \\
\hline Schnute-Richards & & $L(t)=730.91\left(1+(-0.003) e^{-(0.12) t^{2.18}}\right)^{1 / 0.003}$ & \\
\hline
\end{tabular}




\section{Table 2 (on next page)}

Statistical measures of fit for growth models fit to raw age-length data for Gulf Corvina

The Schnute-Richards model fits the data best according to AICC and BIC values, but is only marginally better than the logistic, Gompertz, and von Bertalanffy models. Note: $\mathrm{K}$ indicates the number of parameters in each model.

*3 parameters were estimated by nonlinear least squares, but 4 additional parameters were manually inputted (maximum and minimum ages and lengths) for the Schnute model. 


\begin{tabular}{lcccccc}
\hline Model & K & AICc & $\Delta$ AICc & $\begin{array}{l}\text { AICc } \\
\text { weight }\end{array}$ & BIC & $\Delta$ BIC \\
\hline Schnute-Richards & 6 & 8759.82 & 0.00 & 1 & 8787.42 & 0.00 \\
Logistic & 4 & 8773.62 & 13.80 & 0 & 8792.04 & 4.62 \\
Gompertz & 4 & 8789.69 & 29.87 & 0 & 8808.11 & 20.69 \\
von Bertalanffy & 4 & 8813.66 & 53.84 & 0 & 8832.08 & 44.66 \\
Schnute & $3 *$ & 9148.78 & 388.96 & 0 & 9162.61 & 375.19 \\
\hline
\end{tabular}

1 


\section{Table 3(on next page)}

Parameter estimates for growth models fit to raw Gulf Corvina age-length data bolstered by simulated values

Compared to parameter estimates for models fit to raw data alone, estimates of $L_{\infty}$ are less variable and generally increase. These estimates are closer to the $L_{\infty}$ of 1006 predicted by Froese and Binohlan's (2000) empirical relationship between $L_{\infty}$ and the longest fish in a dataset 


\begin{tabular}{|c|c|c|c|}
\hline Model & & Model fit to data bolstered by simulated values & \\
\hline von Bertalanffy & & $L(t)=951.30\left[1-e^{-0.25(t-(-0.33))}\right]$ & \\
\hline Gompertz & & $L(t)=870.48 e^{\left(-\left(\frac{1}{0.62}\right) e^{-0.62(t-1.34)}\right)}$ & \\
\hline Logistic & & $L(t)=834.34\left[1+e^{-0.62(t-2.10)}\right]^{-1}$ & \\
\hline Schnute & $L(t)=$ & {$\left[141^{-0.78}+\left(1013^{-0.78}-141^{-0.78}\right) \frac{1-e^{-6.06(t-1)}}{1-e^{-6.06(8-1)}}\right]$} & $1 /-0.78$ \\
\hline Schnute-Richards & & $L(t)=938.80\left(1+(-0.0046) e^{-(0.67) t^{0.72}}\right)^{1 / 0.0019}$ & \\
\hline
\end{tabular}




\section{Table 4(on next page)}

Statistical measures of fit for growth models fit to raw Gulf Corvina age-length data bolstered by simulated values

The von Bertalanffy growth model describes the data best according to AICC and BIC values. However, AICC weighting indicates that the Schnute- Richards and Gompertz models have nearly equivalent fits. Note: $\mathrm{K}$ indicates the number of parameters in each model.

*3 parameters were estimated by nonlinear least squares, but 4 additional parameters were manually inputted (maximum and minimum ages and lengths) for the Schnute model. 


\begin{tabular}{lcccccc}
\hline Model & K & AICc & $\Delta$ AICc & $\begin{array}{l}\text { AICc } \\
\text { weight }\end{array}$ & BIC & $\Delta$ BIC \\
\hline von Bertalanffy & 4 & 18678.72 & 0.00 & 0.53 & 18700.20 & 0.00 \\
Schnute-Richards & 6 & 18679.65 & 0.94 & 0.33 & 18711.87 & 11.67 \\
Gompertz & 4 & 18681.29 & 2.57 & 0.15 & 18702.77 & 2.57 \\
Logistic & 4 & 18702.60 & 23.89 & 0 & 18724.09 & 23.89 \\
Schnute & $3 *$ & 19891.72 & 1213.01 & 0 & 19907.84 & 1207.64 \\
\hline
\end{tabular}

1 


\section{Table 5 (on next page)}

Models used to describe growth in sciaenid fishes similar to and including the Gulf Corvina

A review of 24 sciaenid growth studies indicates that sciaenid growth is most commonly modelled by the von Bertalanffy growth model ( 20 studies; $83 \%$ of studies reviewed). 


\begin{tabular}{|c|c|c|}
\hline Growth model selected & Genus and species & References \\
\hline Gompertz & Cynoscion nebulosus & Murphy and Taylor, 1994 (females only) \\
\hline Linear & Cynoscion nebulosus & Murphy and Taylor, 1994 (males only); Nieland et al., 2001 \\
\hline Logistic & Cynoscion nebulosus & Dippold et al., 2016 \\
\hline Schnute-Richards & Cynoscion othonopterus & Aragón-Noriega, 2014 (selected for two datasets); Mendivil-Mendoza, 2017 \\
\hline von Bertalanffy & $\begin{array}{l}\text { Cynoscion nebulosus } \\
\text { Cynoscion othonopterus } \\
\text { Cynoscion regalis } \\
\text { Menticirrhus americanus } \\
\text { Micropogonias funieri } \\
\text { Micropogonias undulates } \\
\text { Pogonias chromis } \\
\text { Sciaenops ocellatus } \\
\text { Totoaba macdonaldi }\end{array}$ & $\begin{array}{l}\text { Rutherford et al., 1982; Maceina et al., 1987; Wieting, 1989; Cottrell, } 1990 \\
\text { Gherard et al. 2013; Aragón-Noriega, } 2014 \text { (selected for two datasets) } \\
\text { Lowerre-Barbieri et al., 1995; Hatch and Jiao, 2016; White, } 2017 \\
\text { Clardy et al., } 2014 \\
\text { Manickchand-Heileman and Kenny, 1990; Santos et al., } 2017 \\
\text { Barger, 1985; Barbieri, 1993; Franco, } 2014 \\
\text { Murphy and Taylor, } 1989 \\
\text { Beckman et al., 1988; Murphy and Taylor, 1990; Ross et al., } 1995 \\
\text { Rodriguez and Hammann, } 1997\end{array}$ \\
\hline
\end{tabular}

